\title{
The Entrepreneurial Education and Self-Efficacy on Entrepreneurial Intention
}

\author{
Yi-Bin Li \\ Business School of Huaqiao University, Quanzhou 362021, China \\ Business Management Research Center, Huaqiao University, Quanzhou 362021, China
}

\begin{abstract}
Based on external entrepreneurship training, selfentrepreneurship learning and inner ability perception, the effects of undergraduates' entrepreneurial education and selfefficacy on their entrepreneurial intention. The results show that (1) undergraduates' entrepreneurial education has a significant positive effect on their entrepreneurial intention, but has no obvious effect on the entrepreneurial attitude. (2) Undergraduates' entrepreneurial self-efficacy has a significant positive effect on the entrepreneurial attitude and entrepreneurial intention, and the entrepreneurial attitude plays a partial intermediary role in the relationship between entrepreneurial self-efficacy and entrepreneurial intention.
\end{abstract}

Keywords-Entrepreneurial Education, Entrepreneurial Self-Efficacy, Entrepreneurial Attitude, Entrepreneurial Intention

\section{INTRODUCTION}

Under the support of the Internet and mobile internet technology, undergraduates' entrepreneurship is on the upsurge in China in past years and becomes more intense because Chinese government promulgates various encouragement policies and releases positive signals. Under the appeal of "doing business creatively and driving innovation" and "optimizing employment and entrepreneurial environment, practicing constant employment and entrepreneurial service, and enhancing undergraduates' employment and entrepreneurship proportion" by Chinese government senior officials, colleges and universities in China actively innovate the entrepreneurial education model and provide entrepreneurial courses and training service for undergraduates through entrepreneurial class, entrepreneurial contest, and entrepreneurial sand table, expecting to enhance undergraduates' entrepreneurial intention and entrepreneurial success rate[1][2].

\section{LITERATURE REVIEW}

Entrepreneurial education aims to develop and enhance students' entrepreneurial quality and cultivate students' enterprise, initiative, pioneering spirit, and spirit of adventure for engaging in certain career, enterprise, and business planning. The fundamental objective of entrepreneurial education lies in developing strategic resources and capability required for entrepreneurs and assisting them in exploding and identifying entrepreneurial opportunities. Various entrepreneurial training activities held inside and outside schools are gradually emphasized in past years, as most participants in entrepreneurial training have made up their minds for entrepreneurship or perceived inadequate entrepreneurial knowledge and capability after starting businesses, expecting to reinforce personal entrepreneurial competency to further inspire the capability of creating, controlling, and pursuing opportunities by participating in entrepreneurial training [3].

Entrepreneurs regard strong entrepreneurial intention as the requirement for creating new career. Entrepreneurial intention refers to individual belief in the preparation for entrepreneurial action to implement entrepreneurial behavior[4]. It could be comprehended as individual planned behavior to start new career that it is a prerequisite for entrepreneurs with entrepreneurial intention[5].McMullan et al.[6] found out the incentive of entrepreneurial education to individual entrepreneurial idea and behavior. Botha et al.[7] suggested regarding entrepreneurial intention as the goal of entrepreneurial education. Entrepreneurial education and training could strengthen individual entrepreneurial intention[8]. Saulo et al.[9]also discovered that entrepreneurial training courses could reinforce entrepreneurs' entrepreneurial intention and entrepreneurial behavior and enhance the entrepreneurial performance. It is therefore considered in this study that entrepreneurial courses and education comment could cultivate relevant entrepreneurial knowledge and skills of undergraduates with entrepreneurial tendency or potential to present knowledge and capability required for the future entrepreneurship and to further enhance the probability of successful entrepreneurship in the future.

Hypothesis 1: Entrepreneurial education presents positive effects on undergraduates' entrepreneurial attitude.

Hypothesis 2: Entrepreneurial education shows positive effects on undergraduates' entrepreneurial intention.

A person perceiving self-capability of completing certain tasks presents major effects on the development of the real capability[10]. Applying self-efficacy to entrepreneurship refers to entrepreneurs' confidence to complete tasks and capability required for entrepreneurship in the entrepreneurship planning process, i.e. the confidence in personal capability to complete specific tasks.

Believing in personal capability to effectively utilized knowledge or skills and favorable attitude is necessary for effective behavior. Self-efficacy could predict entrepreneurial achievement, and entrepreneurial intention, to some extent, was determined by entrepreneurial attractiveness and individual perception of entrepreneurial self-efficacy. In other 
words, self-efficacy was the key factor in entrepreneurs overcoming difficulties and accepting challenge and revealed significant effects on entrepreneurial intention. Past research findings showed that entrepreneurial self-efficacy could positively affect entrepreneurial intention[11]. As a result, it is considered in this study that self-efficacy appears positive correlations with entrepreneurial intention, i.e. positive effects of confidence in resources and capability required for creating new career on entrepreneurial intention. In sum, it is proposed in this study that the higher control of self-efficacy, the higher entrepreneurial intention of entrepreneurs.

Hypothesis 3: Undergraduates' entrepreneurial selfefficacy presents positive effects on the entrepreneurial attitude.

Hypothesis 4: Undergraduates' entrepreneurial selfefficacy shows positive effects on the entrepreneurial intention.

Mitchell et al.[12]regarded entrepreneurial attitude as various response capability, required capability, and adopted perspective in the entrepreneurial process. Van, Boshoff and Bester[13]defined entrepreneurial attitude as predictable and changeable entrepreneurial thinking and feeling. Both Theory of Reasoned Action (TRA) and Theory of Planned Behavior (TPB) explain individual attitude towards behavior as the primary variable to explain individual behavioral intention and point out basic beliefs in such behavior and evaluations of possible result practicing such behavior as the antecedents of individual attitude towards behavior [14][15]. Entrepreneurial education discussed in this study covers undergraduates' selfentrepreneurial learning and entrepreneurial course learning and training offered by colleges and universities or relevant institutions in the society that it could comprehensively reflect individual entrepreneurial learning behavior. Accordingly, it is considered in this study that undergraduates' entrepreneurial attitude presents mediation in the process of entrepreneurial education and entrepreneurial self-efficacy influencing entrepreneurial intention.

Hypothesis 5: Undergraduates' entrepreneurial attitude presents mediation on the relationship between entrepreneurial education and entrepreneurial intention.

Hypothesis 6: Undergraduates' entrepreneurial attitude reveals mediation on the relationship between entrepreneurial self-efficacy and entrepreneurial intention.

\section{METHODS}

In this study, entrepreneurial education covers entrepreneurial courses and practical training offered by external organizations, including schools, and undergraduates' self-entrepreneurial learning to develop 4 clauses for the measurement, and the Cronbach's Alpha appears 0.853 . Referring to the scales of Lucas \& Cooper[16]and Barakat et al.[17], 4 clauses are applied to measure entrepreneurial selfefficacy, and the Cronbach's Alpha is 0.858. Referring to the research result of Robinson et al.[18], 5 clauses are used for measuring entrepreneurial attitude, and the Cronbach's Alpha shows 0.85. Referring to the research results of
Thompson[19], 4 clauses are applied to measure entrepreneurial intention, and the Cronbach's Alpha is 0.881 .

Questionnaire survey is utilized in this study for collecting data. More than 800 undergraduates of colleges and universities in Fujian are distributed the questionnaire, and 412 copies are retrieved, with the retrieval rate $51.5 \%$. The final valid samples are 327, and the questionnaire effective rate reveals $79.3 \%$. Frequency scaling method is utilized for analyzing the sample characteristics of respondents. In terms of gender, the proportion of males $(63.3 \%)$ is far more than females $(36.7 \%)$. Regarding age, most students $(79.8 \%)$ are aged above 21-23. In regard to schools and professionalism, most sample objects are students of Huaqiao University $(66.7 \%)$ and major in arts $(81 \%)$ like economic management, literature, art, philosophy, and public management. In terms of year in college, more than half respondents are senior students $(63.3 \%)$.According to the discussed problems and objectives, this study is divided into three stages.

\section{CONCLUSION}

First explain the primary effects of undergraduates' entrepreneurial education and entrepreneurial self-efficacy on the entrepreneurial intention, but the relationship is not discussed in the previous psychological model. Based on Expectancy-Value Theory, Theory of Reasoned Action, and Theory of Planned Behavior, the relationship between entrepreneurial education, entrepreneurial self-efficacy and entrepreneurial intention is proceeded preliminary theory discussion and empirical test in this study and supplements and improves the current entrepreneurial psychological model and the relevant research. Second, the relationship between undergraduates' entrepreneurial learning, perceived entrepreneurial capability and entrepreneurial intention is proven in this study. There was research on the relationship between entrepreneurial education, self-efficacy and entrepreneurial intention, but the theoretical analyses and empirical tests on the relations between learning, capability perception and the three were few. To sum up, entrepreneurial education and entrepreneurial self-efficacy are regarded as independent variables and entrepreneurial attitude as the mediator in this study to construct the effect model on undergraduates' entrepreneurial intention and to test and supplement TPB from the perspectives of individual learning and perception. The conclusions could be the empirical reference of relevant theories and deepen the successive studies.

\section{References}

[1] Sadi, O., \& Uyar, M., The Relationship Between Self-Efficacy, SelfRegulated Learning Strategies and Achievement: A Path Model. Journal of Baltic Science Education, 12(1), 2013, 21-33.

[2] Huang, L. F., Chiang, C. C., \& Chen, H. C., Willingness to Pay of Visitors for the Nature-based Public Park: An Extension of Theory of Planning Behavior (TPB). Journal of Information and Optimization Sciences, 35(5-6), 2013, 405-429.

[3] Wu, T. J., \& Tai, Y. N., Effects of multimedia information technology integrated multi-sensory instruction on students' learning motivation and outcome. EURASIA Journal of Mathematics, Science and 
Technology Education, 12(4), 2017, 1065-1074.

[4] Krueger, N. F., Reilly, M. D., \& Carsrud, A. L., Competing models of entrepreneurial intentions. Journal of Business Venturing , 15 (5/6), 2000, 411-432.

[5] Premalatha, U. M., An empirical study on the impact of training and development on women entrepreneurs in Karnataka. The IUP Journal of Soft Skills, 3(5), 2010, 49-64.

[6] McMullan, W., Chrisman, J., \& Vesper, K., Lessons from successful innovations in entrepreneurial support programming, In: Chrisman, J., Holbrook, J., Chua, J. (Eds.), Innovation and Entrepreneurship in Western Canada: From Family Businesses to Multinationals. University of Calgary, Calgary, Alberta, 2002, 207-223.

[7] Botha, M., Nieman, G., \& Vuuren, J. V., Measuring the effectiveness of the women entrepreneurship programme as a training intervention. Paper presented at the IntEnt 2006 Conference, Fundação Getulio Vargas, São Paulo, Brazil. 2006.

[8] Igor, P., \& Mateja, D., Conceptualizing academic-entrepreneurial intentions: an empirical test. Technovation, 30, 2010, 332-37.

[9] Saulo D., Barbosa, J. K., \& Brett, R. S., The road less intended: integrating entrepreneurial cognition and risk in entrepreneurship education. Journal of Enterprising Culture, 16(4), 2008, 411-439.

[10] Benight, C. C., \& Bandura, A., Social cognitive theory of posttraumatic recovery: the role of perceived self-efficacy. Behaviour Research \& Therapy, 42(10), 2004, 1129-1148.

[11] Martin, B. C., McNally, J. J., \& Kay, M. J., Examining the formation of human capital in entrepreneurship: a meta-analysis of entrepreneurship education outcomes. Journal of Business Venturing, 28(2), 2013, 211-
224.

[12] Mitchell, R. K., Busenitz, L., Lant, T., McDougall, P. P., Morse, E. A., \& Smith, J. C., Toward a theory of entrepreneurial cognition: Thinking the people side of entrepreneurship research. Entrepreneurship Theory and Practice, 28, 2002, 93-104.

[13] Van, W. R., Boshoff, A. B., \& Bester, C. L., Entrepreneurial attitudes: what are their sources? South African Journal of Economic and Management Sciences, 6(1), 2003, 1-24.

[14] Ajzen, I., \& Fishbein, M., Understanding Attitudes and Predicting Social Behavior. NJ: Prentice Hall.1980.

[15] Ajzen, I., The theory of planned behavior. Organizational Behavior \& Human Decision Processes, 50(2), 1991, 179-211.

[16] Lucas, W., \& Cooper, S., Measuring entrepreneurial self-efficacy, working paper prepared for the EDGE conference. Bridgeing the Gap: Entrepreneurship in theory and practice. 2005.

[17] Barakat, S., Boddington, M., \& Vyakarnam, S., Measuring entrepreneurial self-efficacy to understand the impact of creative activities for learning innovation. International Journal of Management Education, 12, 2014, 456-468.

[18] Robinson, P. B., Stimpson, D. V., Huefner, J., \& Hunt, K., An Attitude Approach to the Prediction of Entrepreneurship. Entrepreneurship Theory and Practice, 15(4), 1991, 13-31

[19] Thompson, \& Edmund, R., Individual entrepreneurial intent: construct clarification and development of an internationally reliable metric. Entrepreneurship Theory \& Practice, 33(3), 2009, 669-694. 